\title{
Winter seabird distribution and abundance off south-western Greenland, 1999
}

\author{
Flemming Ravn Merkel, Anders Mosbech, \\ David Boertmann \& Louise Grøndahl
}

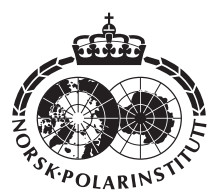

South-western Greenland constitutes an internationally important wintering area for many seabird species. Several species of management concern have a predominantly near-coastal distribution, though available information about seabird numbers is mostly confined to offshore waters. Here we report on extensive aerial surveys conducted in March 1999, covering the coastal waters (up to $15-20 \mathrm{~km}$ from the mainland coast) and fjords of south-west Greenland. The most widespread and numerous species were estimated as 463000 common eiders (Somateria mollissima), 153000 king eiders (S. spectabilis), 125000 thick-billed murres (Uria lomvia), 94000 long-tailed ducks (Clangula hyemalis), and 12000 black guillemots (Cepphus grylle). A total of 19 bird species were recorded. The estimates for common eider and long-tailed duck approximately represent the entire winter population in south-western Greenland while estimates for the other species represent only an unknown proportion since their distribution continues further offshore. Waters around Nuuk and within the Julianehåbsbugten (Julianehåb Bay) area were identified as areas of high seabird density. A large proportion of the common eider population was aggregated in the fjord systems (22\%), calling attention to the importance of fjords for this species. In contrast, pelagic seabird species appear to be absent from the fjords. The large winter population of common eider reveals the importance of south-western Greenland as a key wintering area for the eastern Canadian breeding population. The western Greenland breeding population is the only other contributor, probably amounting to no more than 15000 pairs.

F. R. Merkel, Greenland Institute of Natural Resources, Box 570, DK-3900 Nuuk, Greenland; A. Mosbech, D. Boertmann \& L. Grøndal, National Environmental Research Institute, Dept. of Arctic Environment, Frederiksborgvej 399, DK-4000 Roskilde, Denmark.

The South-west Greenland Open Water Area is known to be an important overwintering area for several seabird species, including common eider (Somateria mollissima), king eider (S. spectabilis) and thick-billed murre (Uria lomvia), when Baffin Bay and the northern and western part of Davis Strait become ice-covered (Brown \& Nettleship 1981). It provides staging and wintering areas for huge numbers of birds which in the summer occur at breeding grounds further north in western Greenland or in neighbouring Arctic countries. Marine birds migrate from the eastern Canadian Arctic, north-west Greenland, Iceland, Norway and Russia to winter here (Salomonsen 1967, 1990; Abraham \& Finney 1986; Reed \& Erskine 1986; Boertmann 1994; Mosbech \& Boertmann 1999; Mosbech \& Johnson 1999).

The international signficance of the Greenland 
Open Water Area has great management and conservation implications for Greenland and circumpolar nations. Oil pollution may threaten seabirds in the future if current exploratory activities develop. Subsistence and commercial winter harvests are currently the most serious regional threat to seabirds. Subsistence harvest of seabirds in west Greenland has occurred at relatively low levels for hundred of years. However, human population growth, combined with technological advances in guns and boats, has increased harvest levels in recent decades (Nielsen 1999; Hansen 2002). Hundreds of thousands of seabirds are shot each year, the majority taken during winter in south-western Greenland (Frich 1997a, 1997b; Denlinger \& Wohl 2001).

The sustainability of the Greenland winter seabird harvest is of great concern in both Canada and Greenland. The resident breeding thick-billed murre population in western Greenland has decreased seriously during the past 50 years, and it is likely that the overall decline may be as high as $50 \%$ (Kampp et al. 1994). Recent ground surveys have documented declines of up to $80 \%$ on common eider breeding grounds in mid- and north-western Greenland (Boertmann et al. 1996; Frich et al. 1998; Merkel 2002). Furthermore, the number of king eiders from the eastern Arctic moulting in fjords and coastal waters off western Greenland during JulySeptember has suffered at least a $50 \%$ decline (Mosbech \& Boertmann 1999). Circumstantial evidence links these declines to the winter harvest in south-western Greenland (Falk et al. 1997; Mosbech \& Boertmann 1999; Natturufrædistofnun Islands 2000; Falk \& Kampp 2001). However, more information on distribution and total abundance during winter is needed for these species to reliably assess the sustainability of the winter harvest in this region. For many marine species, this information might be achieved most effectively by monitoring in winter, when some species are less widely distributed.

Here we report on the results of an extensive aerial survey of seabirds found in fjords and coastal waters in south-western Greenland during winter. Seabird distribution in late mid-winter is presented, and for some species we produce the first available population estimates on the total number of birds wintering in the region. In light of the conservation concerns, the survey design prioritized coastal species. Previous winter surveys have covered only small proportions of the coastal waters in south-west Greenland (Durinck \& Falk 1996; Mosbech \& Boertmann 1999; Mosbech \& Johnson 1999; Heide-Jørgensen et al. 1999). We also present results for several pelagic seabirds, although their offshore distribution ensures that their population was not fully covered by this survey.

\section{Study area}

\section{The South-west Greenland Open Water Area}

Baffin Bay and the western part of the Davis Strait is dominated by the cold, southward flowing Labrador Current. During winter, dense pack ice is formed in this area. On the opposite side, the north flowing West Greenland Current dominates the eastern part of the Davis Strait. The upper layer $(0-150 \mathrm{~m})$ of this current consists of cold water of polar origin from the East Greenland Current, where the bottom layer $(150-800 \mathrm{~m})$ of warmer water originates from the Irminger Current, a branch of the North Atlantic Current (Valeur et al. 1997). Both layers are transported round the southern tip of Greenland, Kap Farvel (Cape Farewell). As they mix and move north, they create a year-round open water area along south-west Greenland-referred to as the Southwest Greenland Open Water Area. It usually extends from Sisimiut $\left(67^{\circ} \mathrm{N}\right)$ in the north to Paamiut $\left(62^{\circ} \mathrm{N}\right)$ in the south (Valeur et al. 1996, 1997; Mosbech et al. 2000). The southern pack ice originates in the Arctic Ocean, and by means of the East Greenland Current flows south to the south-western Greenland coast. It usually passes Kap Farvel in January/February. North of the Open Water Area there is often a narrow lead of open water (West Greenland Coastal Lead) stretching north along the coast or fast ice edge towards Disko Bay. References in this paper to the open water area of south-west Greenland include both the Greenland Open Water Area and the West Greenland Coastal Lead.

\section{Ice conditions during the 1999 survey}

South of $66^{\circ} \mathrm{N}$ the coastal survey area (Fig. 1) was characterized by open water, except for some minor concentrations of drifting brash ice between Maniitsoq and Nuuk, and around Ivittuut. No pack ice from the East Greenland Current had appeared from Kap Farvel at the time of the 
Fig. 1. Aerial survey transects off south-west Greenland covered 27 February to 15 March 1999.

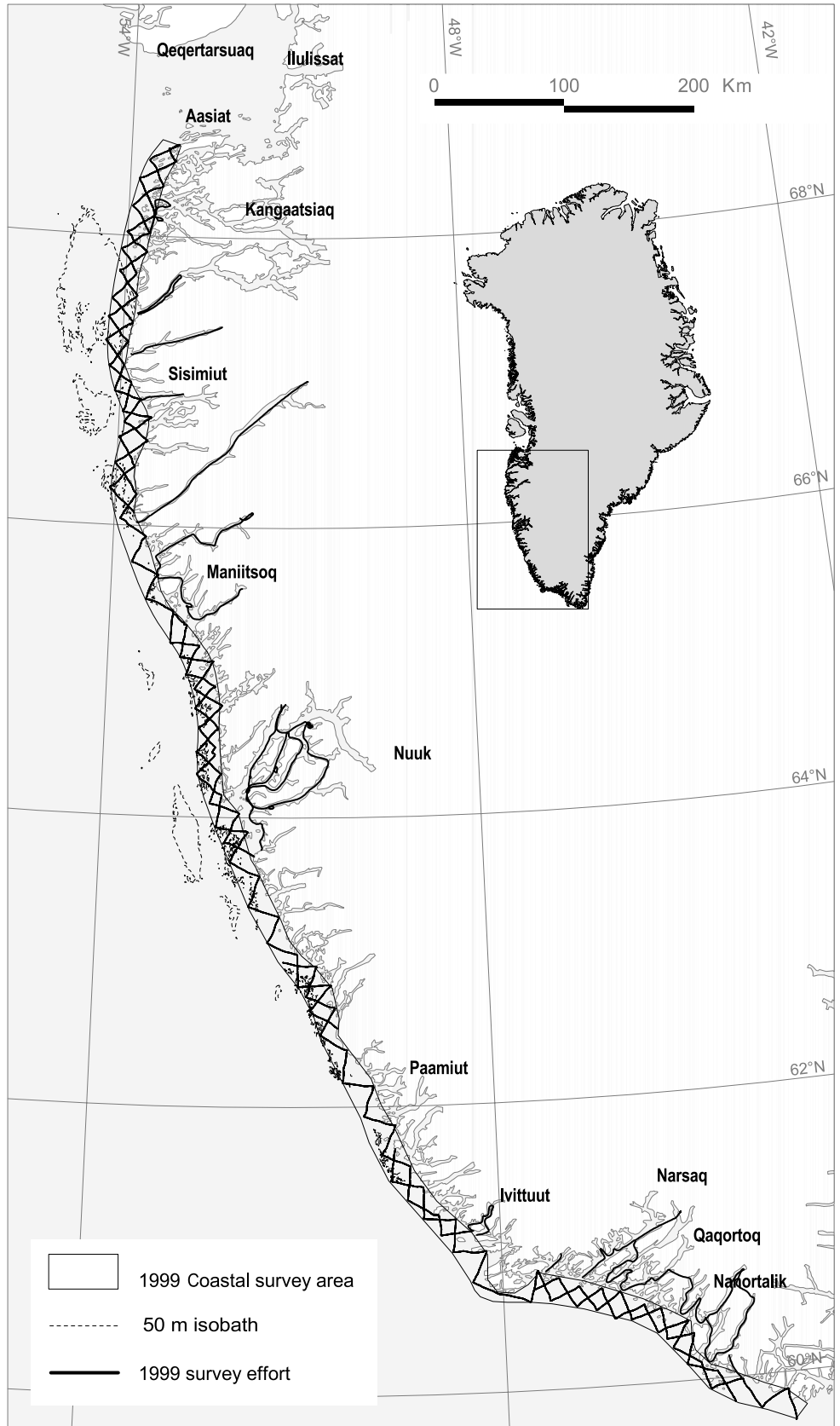

survey. North of $66^{\circ} \mathrm{N}$, the coastal survey area became gradually more ice-covered, and north of $68^{\circ} \mathrm{N}$ heavy pack ice in the Davis Strait extended far to the east and covered most of our coastal survey area. Fjords had higher variable ice conditions, from ice-free to completely ice- covered. In general, though, the interior parts of the fjords were covered with fast ice. Based on the fjords surveyed in this study, for which we have full information about ice coverage, on average $32 \%$ of the fjord areas were covered with fast ice. 


\section{Methods and equipment}

\section{Survey design}

Systematic aerial surveys of seabirds were conducted from 27 February to 15 March 1999. Based on prior knowledge about the overall distribution tendency for various seabird species (Durinck \& Falk 1996; Heide-Jørgensen et al. 1999; Mosbech \& Johnson 1999), this aerial survey was designed to obtain quantitative information on the distribution, abundance and habitat use of seabirds within coastal waters and fjord systems of south-west Greenland.

Within a coastal zone from Aasiat in the north $\left(68^{\circ} 38^{\prime} \mathrm{N}\right)$ to Kap Farvel $\left(59^{\circ} 40^{\prime} \mathrm{N}\right)$, a double set of zigzag transects was assigned. As defined here, the coastal zone extends from the mainland coast to about $15-20 \mathrm{~km}$ to the west (Fig. 1). This zone largely comprises water less than $50 \mathrm{~m}$ deep (though it excludes the $<50 \mathrm{~m}$ deep banks, which are further offshore). However, the coastal zone has a complex and sparsely documented bathymetry and includes many areas with depths greater than $50 \mathrm{~m}$. The coastal zone survey area contained 145 transects with an average length of $24.3 \mathrm{~km}$, making the total transect line 3525 $\mathrm{km}$ long. To minimize off-transect effort, but still crossing any gradient of population density, transects were fixed in a north-east-south-west or north-west-south-east direction. All areas located east of the coastal zone were defined as fjords. The survey route in the fjords followed the coastline, the ice edge or a central line down the fjord.

Survey altitude was decided based on several test surveys conducted in March 1998. Two survey altitudes (250 and 400 feet) were tested for differences in the detectability of seabirds, and three altitudes (250, 400 and 700 feet) were compared regarding the ways the birds responded to the plane's approach. Conducting surveys at high altitudes (400 feet or higher) had the advantages of increasing the effective search width (ESW), with a higher total coverage as a result. Furthermore, flock size estimation varied less at 400 feet compared to 250 feet, maybe because observers had more time to do the estimate/ count. On the other hand, detectability was worse at 400 feet than at 250 feet, mainly because of the greater influence of sea state at higher survey altitudes (Heide-Jørgensen et al. 1999). This is consistent with a more comprehensive study by
Beavers \& Ramsey (1998), who analysed the influence of variables such as weather, time of day, and observers on the detectability of animals in line transect surveys. They concluded that sea state level was the primary variable influencing detectability. We could not expect calm weather (sea state 1 or less) throughout all coastal sections of south-west Greenland, and therefore 250 feet was chosen as the survey altitude for line transects in 1999. Seabird behaviour detected at varying survey altitudes during the 1998 test surveys gave no reason to choose otherwise. Among five species tested-king and common eider, long-tailed duck, thick-billed murre and black guillemot - it was not possible to reduce the level of response caused by the approaching airplane by raising survey altitude to either 400 or 700 feet (Heide-Jørgensen et al. 1999). During line transect surveys we flew at the lowest ground speed possible: $150-170 \mathrm{~km} / \mathrm{h}$ ( $85-95 \mathrm{knots})$.

Total count surveys in the fjords were conducted at a target altitude of $320 \mathrm{~m}$ (1000 feet) and a ground speed of $150-250 \mathrm{~km} / \mathrm{h}$ (85- 140 knots). This high survey altitude was chosen to enable us to cover each fjord with just a single transect. Otherwise, there would be a high risk of detecting identical birds more than once.

\section{Survey effort 1999}

With a total effort of $2863 \mathrm{~km}$, the entire coastal zone was surveyed at least once. Except for six transects north of Maniitsoq, five south of Nuuk, five next to Paamiut and two south of Nanortalik, both sets of zigzag transects were flown (Fig. 1). A total length of $1798 \mathrm{~km}$ was searched in the fjords, and represents nearly complete coverage of the Nuuk fjord system, the Julianehåbsbugten (Julianehåb Bay) fjord system (Fig. 2) and several fjords between Nuuk and Kangaatsiaq (Fig. 1). Except for a minor section, the large and complex fjord system next to Kangaatsiaq was not surveyed. The fjord system was heavily iced at the time of the survey; however, the strong tidal currents in the area maintained ponds of open water, of which some were surveyed. No fjords between Nuuk and the Julianehåbsbugten area were surveyed.

\section{Survey procedures}

Data were collected from a Partenavia P-68 Observer (OY-CAG) aircraft. Two bird observers 
were placed in the seats behind the pilot where bubble windows allowed observations from below the plane (on the track line) and outwards. Observations of birds were made from each of the bubble windows, while the pilot made observations on weather and ice conditions. A third observer in the seat to the right of the pilot collected additional information on seabird behaviour, including their reaction to the approaching aircraft. The airborne observers were the same throughout the survey, except on 15 March 1999, when the rightseated observer was substituted. The observers and the pilot recorded their observations on independent tape recorders by speaking into their headset microphones. When activated, by a hand-held switch, the tape recorders received a synchronized time signal on another track of the same tape from a laptop computer linked to the aircraft's Global Positioning System (GPS). To facilitate later determination of the position of the observations, the position of the aircraft was automatically logged to the laptop computer at eight-second intervals. Altitude from a radar altimeter and ground speed was also logged to the laptop computer.

\section{Observation procedure}

Information about visibility, sea state and ice condition was recorded by the pilot at the starting point of each transect and whenever conditions changed. Sea state was classified using the Beaufort Scale, and surveys were terminated when sea state exceeded Beaufort Scale 3. The ice cover was classified in tenths. Real-time information on ice conditions was also obtained from NOAA-AVHRR satellite images provided by the Danish Meteorological Institute.

Bird sightings in the coastal survey area were recorded according to line transect methodology (Buckland et al. 1993). When a sighted bird or flock was at a right angle to the plane as the aircraft proceeded along the track line (i.e. the bird was abeam the plane), the angle downward to the single bird or the flock's centre on the water was measured by inclinometer. The distance of the observation from the track line was subsequently calculated:

$$
\text { Distance }=\text { altitude } \bullet \tan (90 \text { - angle }) .
$$

In areas of high seabird density angles downward from the aircraft to the birds were measured for only a proportion of bird sightings. For quant- itative analyses, it was assumed that birds observed without known distance from track line were distributed similarly to birds located at known distances.

A flock of birds was defined as two or more birds located close together and exhibiting the same behaviour (e.g. swimming or flying in the same direction), often forming a discrete group on the water. For small groups (less that ca. 20 birds), birds were counted individually. For larger groups, flock size was estimated or an estimated proportion of the flock was counted.

Each bird sighting was classified as: 1) on water, 2) on ice, 3) on ground, 4) about to dive, 5) rising from the water, or 6) flying. Flight direction of flying birds relative to the aircraft was recorded as: a) parallel to the track line, opposite direction of the aircraft; b) parallel to the track line, same direction as the aircraft; c) to the right or to the left, away from the track line; or d) to the left or to the right, towards the transect.

Most taxa were identifiable and recorded as species. However, all large alcids, except for black guillemots (Cepphus grylle), were identified as thick-billed murres (Uria lomvia) although a few may have been common murres (Uria aalge) or razorbills (Alca torda). Little auk (Alle alle) is very difficult to detect due to its small size, and scattered occurrences of this species were probably overlooked. Due to a much higher survey altitude within the fjords, it is also likely that single individuals of various species may have been overlooked there. A small proportion of eider ducks were lumped as undifferentiated eiders (king or common) (Table 1). Except for black-legged kittiwakes (Rissa tridactyla), gull species were not recorded systematically, and are therefore not presented in this paper. Aerial surveys in fjords were conducted as total count surveys, and information about numbers, species and sex was recorded for each sighting.

\section{Analytical methods}

Distance sampling software (version 3.5) was used for quantitative analyses (Thomas et al. 1998). Following Buckland et al. (1993), density $(D)$ of sightings was given as

$$
D=(n \cdot 1 / E S W) / 2 L
$$

where $\mathrm{n}$ is the total number of sightings, ESW is the effective strip width, and $L$ is the total length of transect line searched. The abundance 
estimate, $N$, is thus given as

$$
N=A \cdot s \cdot D
$$

where $A$ is the size of the study area and $s$ is the mean (or corrected) flock size. To evaluate the ESW, we considered three types of models to fit the detection function for the distance data. Each model comprises a key function that can be adjusted by a series expansion containing one or more parameters. The models used were a halfnormal, uniform or hazard-rate key function with either a simple or Hermite polynomial or a cosine series expansion (Buckland et al. 1993). We used the likelihood ratio test to select the number of adjustment terms for the key function, and the value of ESW was obtained from the most likely model with the minimum of Akaike Information Criterion (AIC). The modelling procedure was initially executed on ungrouped sighting data, and subsequently repeated on grouped data. Based on the grouped distance analyses, we carried out a goodness-of-fit chi-square probability test to compare the distribution of our distance data with the expected probability distribution-as expected from the detection function model. In cases where two models produced very similar AIC values, we chose the model that produced the smallest chi-square value. Prior to the modelling process, we truncated obvious outliers, based on visual inspection of the histogram of distances.

When calculating $N$ we distinguished between mean observed flock size and expected flock size (as the expected mean value at distance 0 ). We used the mean observed flock size if size biased regression of $\ln$ (flock size) against estimated $g(x)$ (probability of detection at distance $x$ ) was not significant $(\propto>0.05)$. The intention of this approach is to reduce bias if there is a tendency for smaller flocks to be missed more than larger flocks at large distances from the track line. The confidence interval (95\%) of $N$ was calculated from stratum variation as

$$
\operatorname{var}(N)=N^{2}\left(\operatorname{cv}(E S W)^{2}+\operatorname{cv}(n / L)^{2}+\operatorname{cv}(\mathrm{s})^{2}\right)
$$

(Buckland et al. 1993)

where $c v$ is the coefficient of variation, calculated as the ratio of the standard error to the mean. Assuming a lognormal distribution of $N$ the $95 \%$ confidence interval can be calculated as a lower and upper limit, given as $N / V$ and $N \bullet V$ where

$$
\mathrm{V}=\exp [1.96 * \operatorname{sqrt}\{\operatorname{var}(\ln (N)\}]
$$

(Burnham et al. 1987)

\begin{tabular}{|c|c|c|c|c|c|c|}
\hline & \multicolumn{2}{|c|}{ Coastal area ${ }^{\mathrm{a}}$} & \multicolumn{2}{|c|}{ Fjords } & \multicolumn{2}{|c|}{ Sum } \\
\hline & Sightings & Individuals & Sightings & Individuals & Sightings & Individuals \\
\hline \multicolumn{7}{|l|}{ Seabird species } \\
\hline Fulmar Fulmaris glacialis & 82 & 1153 & & & 82 & 1153 \\
\hline Great cormorant Phalacrocorax carbo & 61 & 556 & 8 & 136 & 69 & 692 \\
\hline Mallard Anas platyrhynchos & 22 & 252 & & & 22 & 252 \\
\hline King eider Somateria spectabilis & 599 & 36352 & 40 & 3582 & 639 & 39934 \\
\hline Common eider Somateria mollissima & 2007 & 56125 & 772 & 103827 & 2779 & 159952 \\
\hline Eider spp Eider spp. & 52 & 9972 & 1 & 130 & 53 & 11002 \\
\hline Harlequin duck Histrionicus histrionicus & 3 & 41 & 1 & 4 & 4 & 45 \\
\hline Long-tailed duck Clangula hyemalis & 413 & 3525 & 4 & 17 & 417 & 3542 \\
\hline Red-breasted merganser Mergus serrator & 28 & 75 & 2 & 4 & 30 & 79 \\
\hline Kittiwake Rissa tridactyla & 24 & 32 & 23 & 3200 & 47 & 3232 \\
\hline Glauceus gull Larus hyperboreus & + & & + & & + & \\
\hline Iceland gull Larus glaucoides & + & & + & & + & \\
\hline Great black-backed gull Larus marinus & + & & + & & + & \\
\hline Thick-billed murre Uria lomvia & 658 & 9993 & 7 & 215 & 665 & 10207 \\
\hline Black guillemot Cepphus grylle & 217 & 796 & 5 & 69 & 222 & 865 \\
\hline \multicolumn{7}{|l|}{ Other bird species } \\
\hline White-tailed eagle Haliaeetus albicilla & 5 & 5 & 2 & 2 & 7 & 7 \\
\hline Gyrfalcon Falco rusticolus & 1 & 1 & & & 1 & 1 \\
\hline Purple sandpiper Calidris maritima & 25 & 399 & 5 & 490 & 30 & 889 \\
\hline Raven Corvus corax & 19 & 34 & 2 & 4 & 21 & 38 \\
\hline
\end{tabular}

and

Table 1. Bird species observed during aerial surveys off south-west Greenland, 27.02 - 15.031999.

${ }^{a}$ Including off-transect observations, made during forced detours from transect lines.

+ Birds present but not systematically recorded. 


$$
\operatorname{var}\left(\ln (N)=\ln \left[1+\operatorname{var}(N) / N^{2}\right]\right.
$$

Determination of the confidence interval on summarized strata is based on the sum of variation from each stratum.

\section{Graphic presentation}

For density calculations the observations were summarized in small areas along the survey transects. Summary areas of $2 \mathrm{~km}$ length were established along the coastal survey transects, and densities for each species and for each summary area were calculated. The widths of the summary areas were the species specific ESW. All observations falling in these areas were summarized into one sum for the area. Areas used for summarizing observed birds in the fjords are approximately $10 \mathrm{~km}$ long. The summarized densities at the coastal area and in the fjords were interpolated using Inverse Distance Weighting to cover all areas within $6 \mathrm{~km}$ from the transect (for fjords, $8 \mathrm{~km}$ ). Using this method each summarized observation is assumed to have a local influence that diminishes with distance. The observation closest to the observation in process is weighted higher than those farther from the observation. For this interpolation each processed unit has an area of $1 \times 1 \mathrm{~km}$ resulting in $1 \mathrm{~km}^{2}$ cells.

\section{Results}

\section{General distribution}

A total of 19 bird species were recorded during the survey, of which we have classified 15 as seabird species (Table 1). Most species had their main distribution area within the coastal survey area or at the outermost regions of the fjord systems. Only common eiders (Fig. 2) and kittiwakes occurred at high densities deep inside fjords. In general, species diversity was highest in the central region of the survey area, from around Maniitsoq south to Fiskenæsset $\left(65^{\circ}-63^{\circ} \mathrm{N}\right)$, and in the Julianehåbsbugten area. Species like fulmar (Fulmaris glacialis), great cormorant (Phalacrocorax carbo), mallard (Anas platyrhynchos), red-breasted merganser (Mergus serrator) and kittiwakes were very rare outside these two areas. There was also a tendency of larger flock sizes and a more patchy distribution north of Sisimiut $\left(67^{\circ} \mathrm{N}\right)$, coinciding with increasing ice coverage to the north.

\section{Quantitative analyses: assumptions}

Five seabird species were included in our quantitative analyses: common eider, king eider, longtailed duck (Clangula hyemalis), thick-billed murre and black guillemot. All sightings of fulmar were of flying birds (Table 2), and therefore not appropriate for distance sampling. Observations of great cormorant were also inadequate for distance sampling since half the sightings were of flying birds, and the rest were taking off from the ground. They had been resting on small islands prior to the approach of the aircraft (Table 2). The rest of the species were too seldomly encountered to allow quantitative spatial analyses (Table 1).

In the process of estimating the abundance of each of the above-mentioned five species, we assumed that birds flying at the time of detection (Table 2) were distributed similarly to birds detected on the water. However, at the time of detection flying birds had moved from their original positions and therefore had to be excluded from the detection function analyses. Flying birds were also excluded from flock size calculation to avoid overestimating the mean flock size. The

Table 2. Seabird behaviour recorded by the backseat observers when passing the birds abeam.

\begin{tabular}{lccccc}
\hline Species & $\begin{array}{c}\text { No. of } \\
\text { sightings }\end{array}$ & $\begin{array}{c}\text { On water } \\
\%\end{array}$ & $\begin{array}{c}\text { Diving } \\
\%\end{array}$ & $\begin{array}{c}\text { Rising } \\
\%\end{array}$ & $\begin{array}{c}\text { Flying } \\
\%\end{array}$ \\
\hline Common eider & 1888 & 74 & 1 & 4 & 22 \\
King eider & 554 & 72 & 2 & 3 & 23 \\
Long-tailed duck & 373 & 61 & 1 & 6 & 32 \\
Thicked-billed murre & 652 & 88 & 8 & 0 & 4 \\
Black guillemot & 201 & 77 & 14 & 3 & 6 \\
Great cormorant & 50 & 0 & 0 & 52 & 48 \\
Fulmar & 81 & 0 & 0 & 1 & 99 \\
Kittiwake & 24 & 0 & 0 & 0 & 100 \\
\hline
\end{tabular}


Table 3. Estimates of wintering eiders, long-tailed duck, thick-billed murre and black guillemot populations off south-west Greenland, 1999, derived from distance sampling analyses. Coastal strata 1 and 2 indicate geographical post-stratifications, whereas A, B and C indicate post-stratification by flock size (further details in Results). Coefficients of variation calculated as standard error in proportion to the mean are indicated in parentheses. (Table continues next page.)

\begin{tabular}{|c|c|c|c|c|c|c|c|c|}
\hline $\begin{array}{l}\text { Species } \\
\text { and stratum }\end{array}$ & $\begin{array}{l}\text { Area } \\
\left(\mathrm{km}^{2}\right)\end{array}$ & $\begin{array}{l}\text { ESW } \\
(\mathrm{km})\end{array}$ & $\begin{array}{c}\text { Right- } \\
\text { truncation } \\
\text { (m, \% sight.) }\end{array}$ & $\begin{array}{l}\text { Key function } \\
+ \text { series expan. }\end{array}$ & $\begin{array}{l}\text { Effort } \\
L(\mathrm{~km}) \\
\end{array}$ & $\begin{array}{c}\% \text { area } \\
\text { surv. }\end{array}$ & $\begin{array}{c}\text { Sightings }^{\mathrm{a}} \\
(n)\end{array}$ & $\begin{array}{c}\text { Sighting } \\
\text { rate } \\
(n / L)\end{array}$ \\
\hline \multicolumn{9}{|l|}{ Common eider } \\
\hline Coastal A, S < 10 & 22250 & $0.140(0.04)$ & $280(6)$ & hazard-rate + s.poly & 2863 & 3.6 & 1440 & $0.50(0.09)$ \\
\hline Coastal $\mathrm{B}, 10 \leq \mathrm{S}<100$ & 22250 & $0.183(0.04)$ & $280(17)$ & uniform + s.poly & 2863 & 4.7 & 256 & $0.09(0.11)$ \\
\hline Coastal C, S $\geq 100$ & 22250 & $0.280(0)$ & $280(17)$ & strip census & 2863 & 7.2 & 27 & $0.01(0.33)$ \\
\hline $\mathrm{A}+\mathrm{B}+\mathrm{C}$ & 22250 & & & & 2863 & 5.1 & 1723 & \\
\hline Fjords & & & & total count & 1798 & & 772 & \\
\hline Total & & & & & 4661 & & 2495 & \\
\hline \multicolumn{9}{|l|}{ King eider } \\
\hline Coastal $1, \mathrm{~S}<100$ & 3227 & $0.139(0.03)$ & $280(2)$ & uniform + s.poly & 486 & 4.2 & 13 & $0.03(0.47)$ \\
\hline Coastal $1, S \geq 100$ & 3227 & $0.280(0)$ & $280(25)$ & strip census & 486 & 8.4 & 16 & $0.03(0.46)$ \\
\hline Coastal 2 & 19023 & $0.139(0.03)$ & $280(2)$ & uniform + s.poly & 2377 & 3.5 & 510 & $0.22(0.12)$ \\
\hline $1+2$ & 22250 & & & & 2863 & & 539 & \\
\hline Fjords & & & & total count & 1798 & & 40 & \\
\hline Total & & & & & 4661 & & & \\
\hline \multicolumn{9}{|l|}{ Long-tailed duck } \\
\hline Coastal 1 & 5198 & $0.109(0.06)$ & $240(4)$ & half-normal & 804 & 3.6 & 16 & $0.02(0.38)$ \\
\hline Coastal 2 & 17052 & $0.109(0.06)$ & $240(4)$ & half-normal & 2059 & 2.6 & 347 & $0.17(0.11)$ \\
\hline $1+2$ & 22250 & & & & 2863 & 2.8 & 363 & \\
\hline \multicolumn{9}{|l|}{ Thicked-billed murre } \\
\hline Coastal A, S $\leq 10$ & 22250 & $0.104(0.02)$ & $300(2)$ & uniform $+\cos$ & 2863 & 2.7 & 383 & $0.13(0.15)$ \\
\hline Coastal B, S > 10 & 22250 & $0.156(0.14)$ & $350(9)$ & half-normal & 2863 & 4.0 & 84 & $0.03(0.20)$ \\
\hline $\mathrm{A}+\mathrm{B}$ & 22250 & & & & 2863 & 3.3 & 467 & \\
\hline \multicolumn{9}{|l|}{ Black guillemot } \\
\hline Coastal & 22250 & $0.16(0.06)$ & $300(2)$ & hazard-rate & 2863 & 4.1 & 172 & $0.06(0.15)$ \\
\hline
\end{tabular}

${ }^{a}$ Number of sightings used for the calculation of sighting rate $(n / l)$. Represents all on-transect sightings, except for those eliminated by truncation. Number of sightings used when calculating ESW and flock size are less than indicated in this column, due to a minor proportion of sightings for which information about flock size or distance from track line is lacking.

Table 4. Estimates of some highly concentrated wintering seabirds in the Nuuk area and in the Julianehåbsbugten area (see Fig. 2 for boundaries). Coefficients of variation calculated as standard error in proportion to the mean are indicated in parentheses. (Table continues next page.)

\begin{tabular}{|c|c|c|c|c|c|c|c|c|}
\hline $\begin{array}{l}\text { Species } \\
\text { and stratum }\end{array}$ & $\begin{array}{l}\text { Area } \\
\left(\mathrm{km}^{2}\right)\end{array}$ & $\begin{array}{l}\text { ESW } \\
(\mathrm{km})\end{array}$ & $\begin{array}{c}\text { Right- } \\
\text { truncation } \\
(\mathrm{m}, \% \text { sight. })\end{array}$ & $\begin{array}{l}\text { Key function } \\
+ \text { series expan. }\end{array}$ & $\begin{array}{l}\text { Effort } \\
L(\mathrm{~km})\end{array}$ & $\begin{array}{l}\% \text { area } \\
\text { surv. }\end{array}$ & $\begin{array}{c}\text { Sightings }^{\mathrm{a}} \\
(n)\end{array}$ & $\begin{array}{c}\text { Sighting } \\
\text { rate } \\
(n / L)\end{array}$ \\
\hline $\begin{array}{l}\text { Common eider } \\
\text { Nuuk-Coast } \\
\text { Nuuk-Fjords } \\
\text { Nuuk-Total }\end{array}$ & 1330 & $0.140(0.07)$ & $280(6)$ & $\begin{array}{r}\text { hazard-rate }+ \text { s.poly } \\
\text { total count }\end{array}$ & $\begin{array}{l}196 \\
510 \\
706\end{array}$ & 4.1 & $\begin{array}{l}267 \\
127 \\
394\end{array}$ & $\begin{array}{r}1.36(0.24) \\
0.25(-)\end{array}$ \\
\hline $\begin{array}{l}\text { King eider } \\
\text { Nuuk-Coast }\end{array}$ & 1330 & $0.132(0.06)$ & $280(2)$ & uniform + s.poly & 196 & 3.9 & 110 & $0.561(0.29)$ \\
\hline $\begin{array}{l}\text { Long-tailed duck } \\
\text { Nuuk-Coast }\end{array}$ & 1330 & $0.096(0.12)$ & & half-normal & 196 & 2.8 & 72 & $0.37(0.24)$ \\
\hline $\begin{array}{l}\text { Common eider } \\
\text { Jul.bugt.-_Coast } \\
\text { Jul.bugt.-Fjords } \\
\text { Jul.bugt.-Total }\end{array}$ & 3558 & $0.133(0.05)$ & $280(6)$ & $\begin{array}{r}\text { half-normal } \\
\text { total count }\end{array}$ & $\begin{array}{r}554 \\
560 \\
1114\end{array}$ & 4.1 & $\begin{array}{l}365 \\
374 \\
739\end{array}$ & $\begin{array}{r}0.66(0.15) \\
0.67(-)\end{array}$ \\
\hline
\end{tabular}

\footnotetext{
${ }^{a}$ Number of sightings used for the calculation of sighting rate $(n / l)$. Represents on-transect sightings, except for those eliminated by truncation. Number of sightings used when calculating ESW and flock size are less than indicated in this column due to a minor proportion of sightings for which information about flock size or distance from track line are lacking.

$\mathrm{b}$ Julianehåbsbugten (Julianehåb Bay), $60^{\circ}-61^{\circ} \mathrm{N}$.
} 


\begin{tabular}{|c|c|c|c|c|}
\hline $\begin{array}{l}\text { Flock } \\
\text { size } \\
S\end{array}$ & $\begin{array}{c}\text { Density } \\
D \\
\left(\text { no. } \mathrm{km}^{-2} \text { ) }\right.\end{array}$ & $\begin{array}{c}\text { Abundance } \\
\text { estimate } \\
N\end{array}$ & \multicolumn{2}{|c|}{$\begin{array}{l}95 \% \text { conf. limits } \\
\text { for estimate }(N)\end{array}$} \\
\hline $2.3(0.03)^{b}$ & $4.2(0.10)$ & 92326 & 75701 & 112603 \\
\hline $23.9(0.06)$ & $5.9(0.13)$ & 130134 & 100862 & 167903 \\
\hline \multirow[t]{2}{*}{$364.3(0.39)$} & $6.1(0.51)$ & 136500 & 53273 & 349747 \\
\hline & & 358960 & 243025 & 530202 \\
\hline \multirow[t]{2}{*}{$134.5(-)$} & & 103834 & - & - \\
\hline & & 462794 & 341573 & 627036 \\
\hline $4.5(0.24)^{b}$ & $0.4(0.53)$ & 1394 & 525 & 3702 \\
\hline $602.5(0.58)$ & $35.4(0.74)$ & 114301 & 31170 & 419145 \\
\hline \multirow[t]{2}{*}{$2.3(0.06)^{b}$} & $1.77(0.13)$ & 33621 & 25929 & 43595 \\
\hline & & 149317 & 52838 & 421957 \\
\hline \multirow[t]{2}{*}{$89.6(-)$} & & 3584 & - & - \\
\hline & & 152901 & 55272 & 422971 \\
\hline $6.9(0.13)$ & $0.6(0.40)$ & 3279 & 1530 & 7029 \\
\hline \multirow[t]{2}{*}{$6.9(0.13)$} & $5.3(0.18)$ & 91103 & 63906 & 129875 \\
\hline & & 94382 & 66943 & 133070 \\
\hline $1.7(0.04)^{\mathrm{b}}$ & $1.1(0.16)$ & 23898 & 17600 & 32449 \\
\hline \multirow[t]{2}{*}{$48.5(0.18)$} & $4.6(0.30)$ & 101542 & 57024 & 180814 \\
\hline & & 125439 & 78091 & 201497 \\
\hline $2.9(0.40)$ & $0.5(0.43)$ & 12030 & 5335 & 27128 \\
\hline
\end{tabular}

${ }^{\mathrm{b}}$ Expected flock size used in preference to mean flock size (see Methods).

\begin{tabular}{|c|c|c|c|c|}
\hline $\begin{array}{l}\text { Flock } \\
\text { size }\end{array}$ & $\begin{array}{c}\text { Density } \\
D\end{array}$ & $\begin{array}{l}\text { Abundance } \\
\text { estimate }\end{array}$ & $\begin{array}{l}95 \% \text { co } \\
\text { for esti }\end{array}$ & $\begin{array}{l}\text { f. limits } \\
\text { ate }(N)\end{array}$ \\
\hline S & (no. $\mathrm{km}^{-2}$ ) & N & lower & upper \\
\hline $3.8(0.11)$ & $18.6(0.27)$ & 24783 & 14664 & 41883 \\
\hline $251.6(-)$ & & 31952 & - & - \\
\hline & & 56735 & 44962 & 71589 \\
\hline $4.1(0.18)^{\mathrm{c}}$ & $8.7(0.35)$ & 11507 & 5947 & 22266 \\
\hline $5.2(0.13)$ & $9.9(0.30)$ & 13232 & 7468 & 23445 \\
\hline $6.2(0.10)^{\mathrm{c}}$ & $15.3(0.18)$ & 54550 & 38353 & 77589 \\
\hline $110.2(-)$ & & 41204 & - & - \\
\hline & & 95754 & 78256 & 117165 \\
\hline
\end{tabular}

$\overline{{ }^{c}}$ Expected flock size used in preference to mean flock size (see Methods).

Merkel et al. 2002: Polar Research 21(1), 17-36 risk of missing single birds or small flocks of birds increases as birds are moving away from the observer. The vast majority of flying birds took a flight direction away from the aircraft (perpendicular to the direction of the aircraft). Second, the risk of perceiving two distinct flocks of birds as a single one also increases as distance increases. Furthermore, we also observed that separate airborne flocks tended to unite in larger groups, as one flock apparently attracted the attention of another. Alternatively, exclusion of flying birds from flock size calculations could cause the mean size to be underestimated. This would occur if larger flocks tended to be more alert than smaller flocks and moved away to avoid the aircraft more often. However, observations from the co-pilot seat did not indicate this. No statistically signficant correlation was found between the distance from which eiders took flight and the flock size for either species: $r=0.19$ for common eider $(n=49) ; r=0.09$ for king eider $(n=23)$; and $r=0.21$ for both species combined $(n=74)$.

To include the "flying bird proportion" in the final estimate, sightings were entered when computing the mean sighting rate. A certain proportion of the sightings have been truncated, similar to the one effected on birds on the water. As the original position of the flying birds is unknown, we risk including birds that were originally outside the truncation distance. We suggest that this potential source of error may be counterbalanced by the risk of missing "inside" birds more often than expected from the detection function, due to a far-off position at the time of detection.

\section{Common eider}

Common eider had the most wide-ranging distribution and was also the most abundant species (Table 1). A total of 2779 sightings were recorded during the survey, of which $28 \%$ were made in the fjords. In general, sighting rate was high and flock size low at the coastal zone, whereas the opposite applied in the fjords. Only in the most northern part of the coastal zone, north of $68^{\circ} \mathrm{N}$, was flock size high as in the fjords. At the coastal zone, common eiders were most frequently seen on near-shore shallow waters (Fig. 2).

On average, $74 \%$ of the sightings at the coastal zone were birds detected on the water, while the majority of the rest were flying when passed 
Fig. 2 (right). Distribution and interpolated densities of common eider in south-west Greenland, February/March 1999.

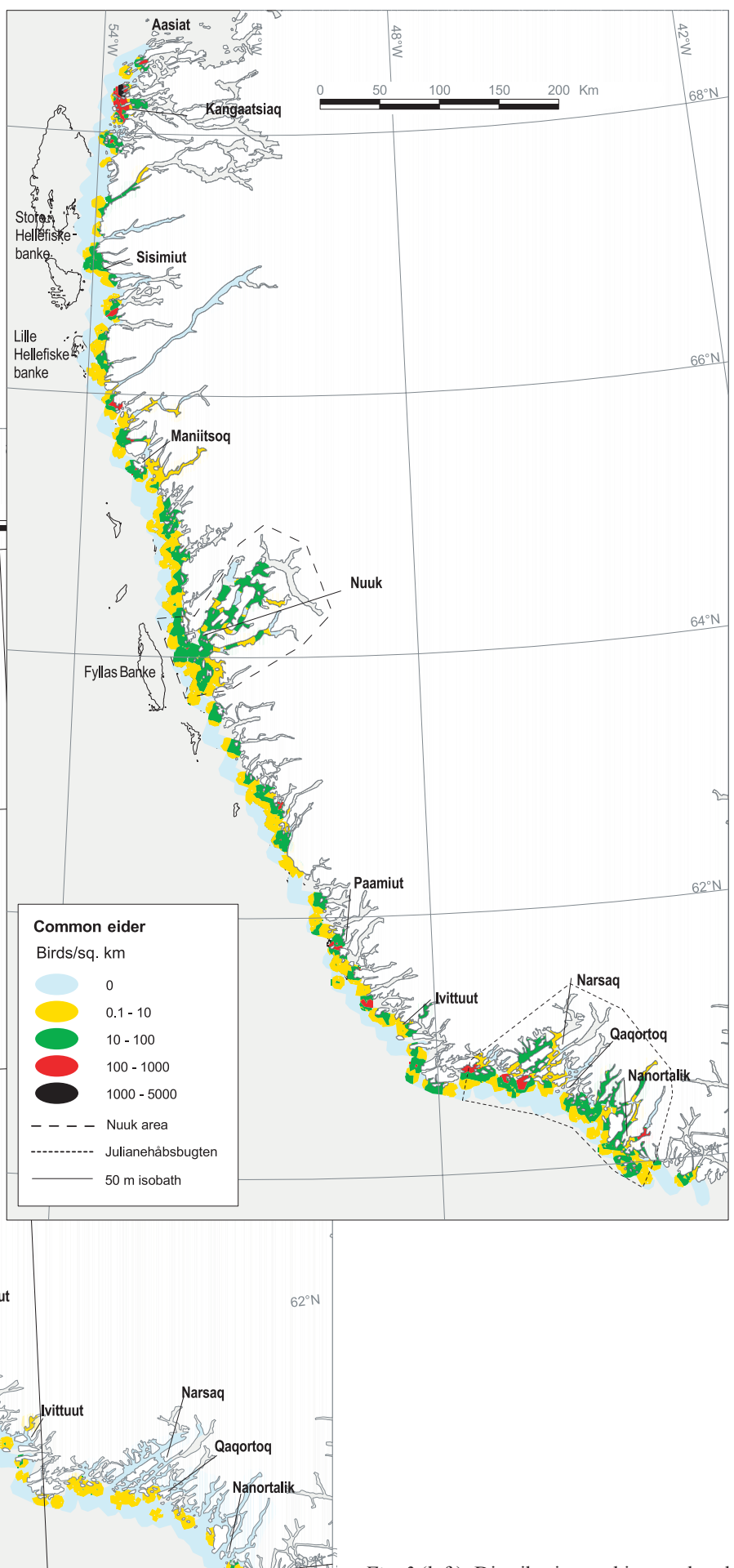

Fig. 3 (left). Distribution and interpolated densities of king eider in south-west Greenland, February/March 1999. 
abeam (Table 2). Splitting this dataset at $66^{\circ} \mathrm{N}$, $64^{\circ} \mathrm{N}$ and $62^{\circ} \mathrm{N}$ showed that the proportion of flying birds versus birds on the water was significantly higher in the most northern area (north of $66^{\circ} \mathrm{N}$ ): $51 \%$ flying birds in the northern area compared to $18 \%, 10 \%$ and $23 \%$ at the three southern areas $\left(\chi_{3}^{2}=181.4 ; P<0.01\right)$.

When estimating common eider abundance, the coastal survey zone was analysed as only one stratum due to the rather continuous distribution of birds along the outer coastline (Fig. 2). However, we post-stratified data according to flock size to overcome a very high degree of natural variation from this source. With flock sizes of 10 and 100 individuals as the points of separation, three datasets were produced. Each dataset was analysed separately (Coastal A, B and C) (Table 3). By assuming a 100\% detection efficiency of large eider flocks $(\geq 100)$ within the whole transect width $(2 \times 280 \mathrm{~m})$, dataset $\mathrm{C}$ was analysed according to strip census methodology. Flock size varied considerably (from 100 to 6500 birds). In dataset $C$, however, additional stratification was not possible because of the small sample size. The total number of common eiders at the coastal stratum was estimated at 358960 birds (95\% CL: 243025 -530202). Combined with a total count of 103834 birds in the fjords, the total number of common eiders is estimated at 462794 birds (95\% CL: 341573 - 627 036) (Table 3).

At the coastal stratum there was a rather consistently high density of common eiders west of Nuuk $\left(64^{\circ} \mathrm{N}, 18.6\right.$ birds $\left./ \mathrm{km}^{2}\right)$ and in the Julianehåbsbugten area (15.3 birds $\left./ \mathrm{km}^{2}\right)$ (Table 4). Along with high densities in the adjoining fjords, these areas constituted two very important common eider wintering sites in 1999 (Fig. 2). Based on separate analyses we estimated 56735 (95\% CL: $44962-71589$ ) common eiders in the Nuuk area, and 95754 (95\% CL: 78256 - 117 165) in the Julianehåbsbugten area. In both cases, approximately half the birds were located in the fjords (Table 4). A third area of equal importance may be the northern area between $67^{\circ} 15^{\prime}$ and $68^{\circ} 45^{\prime} \mathrm{N}$. Most observations of large eider flocks at the coastal stratum were detected here, leading to a high density around Kangaatsiaq. Due to poor coverage we are unable to document the importance of the adjoining fjords in this region.

\section{King eider}

Like common eider, king eider had a wide- ranging distribution at the coastal zone. However, in contrast to common eider, few king eiders were present in the fjords (Fig. 3). Only 6\% out of 639 sightings were detected in fjords (Table 1); king eiders were seen deep inside the fjords on only two occasions. Compared to common eiders, king eiders had a more uniform east-west distribution at the coastal zone, as they occupied deeper waters to the west. By sightings, king eider was the third most abundant species, the second most abundant when evaluated by number (Table 1).

King eider behaviour was very similar to common eider behaviour (Table 2). $72 \%$ of the king eider sightings in the coastal zone were detected on the water, while $23 \%$ were flying when passed abeam. As with common eider, the proportion of flying king eiders versus birds on the water were significantly higher to the north $\left(\chi_{3}^{2}=45.6 ; P<0.01\right)$. North of $66^{\circ} \mathrm{N}, 43 \%$ of the sightings were airborne compared to only $11 \%$, $19 \%$ and $25 \%$ south of $66^{\circ} \mathrm{N}, 64^{\circ} \mathrm{N}$ and $62^{\circ} \mathrm{N}$, respectively.

North of Sisimiut $\left(67^{\circ} \mathrm{N}\right)$ flock size was considerably higher than elsewhere at the coastal zone. As a consequence, the coastal zone was divided into two strata (Fig. 3), and distance data subsequently post-stratified and analysed according to this (Table 3). Furthermore, data from the northern stratum 1 were stratified according to flock size to overcome some of the variation from this source. As with the common eider, sightings of large king eider flocks $(\geq 100)$ were analysed as strip census data, as we assumed $100 \%$ detection efficiency within the truncation distance $(280 \mathrm{~m})$. The king eider coastal population was estimated at 149317 birds (95\% CL: $52838-421$ 957), of which ca. 78\% originated in the northern stratum 1 (Table 3). Another 3584 birds were detected in the fjords, making a total estimate of 152901 (95\% CL: 55272 - 422971) king eiders. As indicated by the wide-ranging confidence limits, the abundance estimate is subject to major uncertainties. This is mainly due to the low sample size and wideranging flock size in coastal stratum 1 (Table 3 ). In contrast, sighting rate was high and flock size very uniform in stratum 2 , and led to a much more accurate estimate of 33621 (95\% CL: 25929-43 595).

Densities within stratum 2 were highest west off Nuuk $\left(8.7\right.$ birds $\left./ \mathrm{km}^{2}\right)$, as was the case for common eider. A separate analyses estimated that 11507 (95\% CL: 5947-22 266) king eiders 
Fig. 4 (right). Distribution and interpolated densities of long-tailed duck in south-west Greenland, February/March 1999.

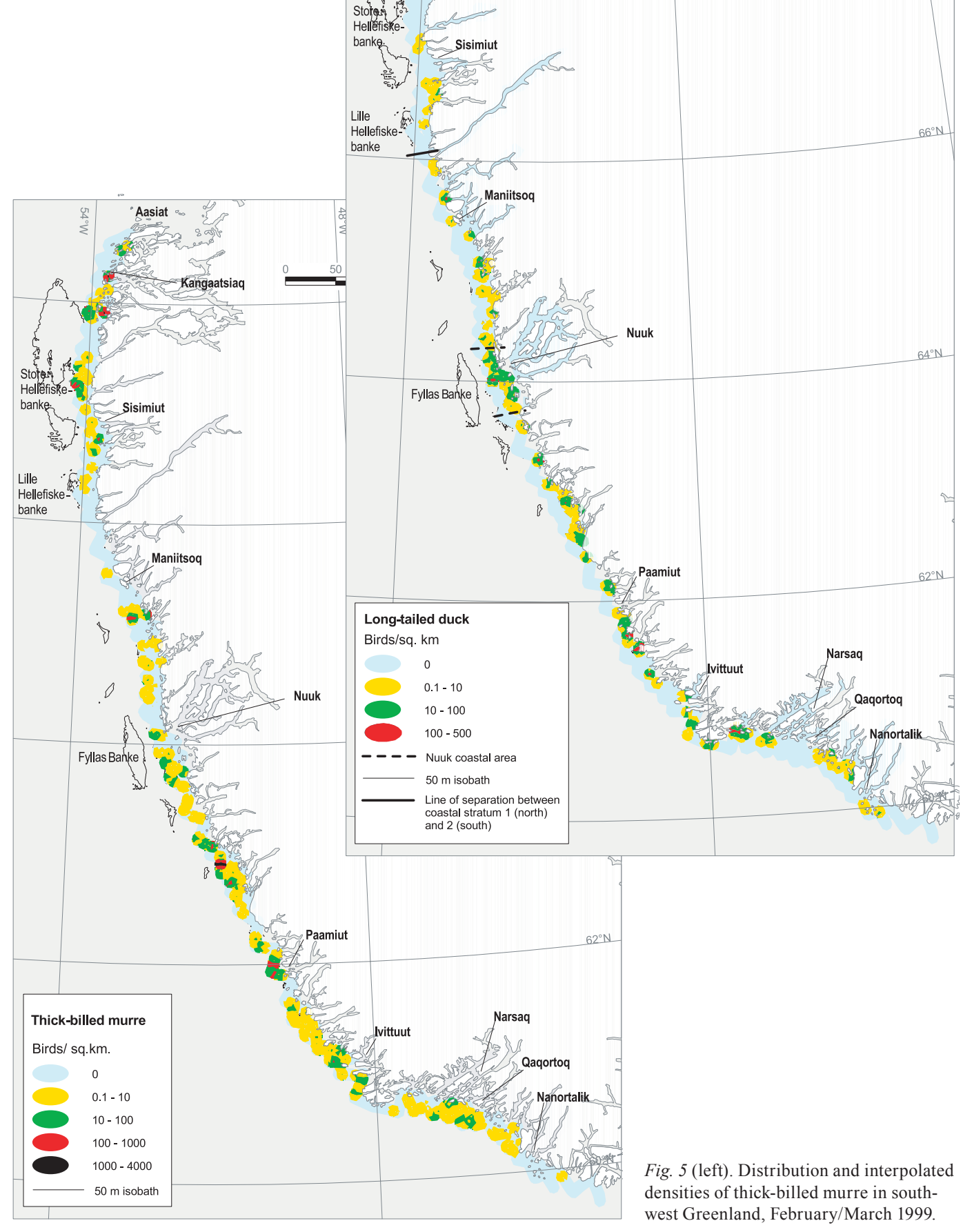


were present at the coastal zone just west of Nuuk $\left(1330 \mathrm{~km}^{2}\right)$ (Fig. 3, Table 4).

\section{Unidentified eiders}

A total of 53 sightings were recorded as undifferentiated eiders. This constituted $1.5 \%$ of all eider sightings (Table 1). Almost all of them were seen at the coastal zone north of Sisimiut. The vast majority was detected at very long distances (300-4000 m), which accounts for why they could not be identified to species. Most were gathered in large flocks, which explains why they were detected. All of these observations were disregarded in the quantitative analyses of eiders, as they would have been eliminated by truncation.

\section{Long-tailed duck}

Long-tailed ducks occurred entirely in nearshore coastal waters (Table 1, Fig. 4). Birds were distributed throughout the coastal zone, however. North of Nuuk $\left(64^{\circ} \mathrm{N}\right)$ they became gradually less frequent, and north of Søndre Strømfjord $\left(66^{\circ} \mathrm{N}\right)$ they were rare (stratum 1$)$.

The proportion of long-tailed ducks that were detected as flying when passed abeam was higher than for both eider species - on average 32\%. Still, the majority of long-tailed ducks were detected on the water $(61 \%)$ (Table 2). Again, the proportion of flying birds versus birds on the water was significantly higher than in the north $\left(\chi_{3}^{2}=17.9 ; P<0.01\right)$, with $56 \%$ of airborne sightings north of $66^{\circ} \mathrm{N}$ compared to only $26 \%$, $29 \%$ and $37 \%$ south of $66^{\circ} \mathrm{N}$.

Compared to the eiders, long-tailed duck flock size variation was small (120 birds being the highest number recorded). Instead, substantial variance was added to the abundance estimate as a consequence of a rather variable sighting rate. To overcome some of it, distance data were post-stratified according to a northern and southern stratum, and a separate sighting rate was computed for each of them (Table 3). However, mean flock size and ESW was computed from all sightings. The distance analyses led to an estimated number of 94382 (95\% CL: 66943 - 133 070) wintering long-tailed ducks, of which only $3.5 \%$ (3279 birds) originated in the northern stratum 1 (Table 3 ).

Once more, the Nuuk coastal zone turned out to be a high-density area at the time of the survey. We estimated that 13232 (95\% CL: 7468 -23 445) long-tailed ducks were present in the Nuuk coastal zone (Table 4). The average density of birds in this area was approximately twice the overall density of stratum 2 (10.0 birds/ $\mathrm{km}^{2}$ versus 5.3).

\section{Thick-billed murre}

The thick-billed murre was the second most frequent species encountered, by sightings (Table 1). Birds were seen throughout most of the coastal zone, although they were absent or scarce from around Maniitsoq $\left(65^{\circ} \mathrm{N}\right)$ and $150 \mathrm{~km}$ to the north, and in a few minor areas elsewhere at the coastal zone (Fig. 5). Just as king eiders, the murres had a rather uniform east-west distribution within the coastal survey area, indicating that their presence continued further west. Very few birds were seen in the fjords (Table 1), and all were detected at the outermost regions of the fjord systems (Fig. 5).

Murres performed escape diving as the most pronounced response to the approaching survey airplane. On average, $8 \%$ of the sightings were detected as diving birds when passed abeam (Table 2). Usually birds were visible several metres below the surface. Murres initially responded by swimming away from the flight path, and then some escaped by diving as the plane passed over them. There was a tendency for escape diving to occur most frequently close to the flight line. In a number of cases, birds did not dive until the airplane had already passed over them. In such cases birds were recorded as being "on the water". Therefore, the true magnitude of murres responding to the approaching airplane was probably somewhat higher than indicated by our records (Table 2). The proportion of diving birds versus birds on the water differed significantly between areas $\left(\chi_{3}^{2}=15.3 ; P<0.01\right)$. Escape diving response was most pronounced between $66^{\circ}$ and $62^{\circ} \mathrm{N}(12-14 \%)$, and less so north and south of this area (2-6\%). The number of airborne sightings also varied between areas, though in general few murres took flight (Table 2).

Murres often occurred singly or in small flocks ( $\leq 10$ birds). However, for a minor proportion $(20 \%)$ of the sightings flock size ranged considerably (11 - 2000 birds). To reduce variance from this source we stratified the murre dataset according to flock size, with 10 individuals as 


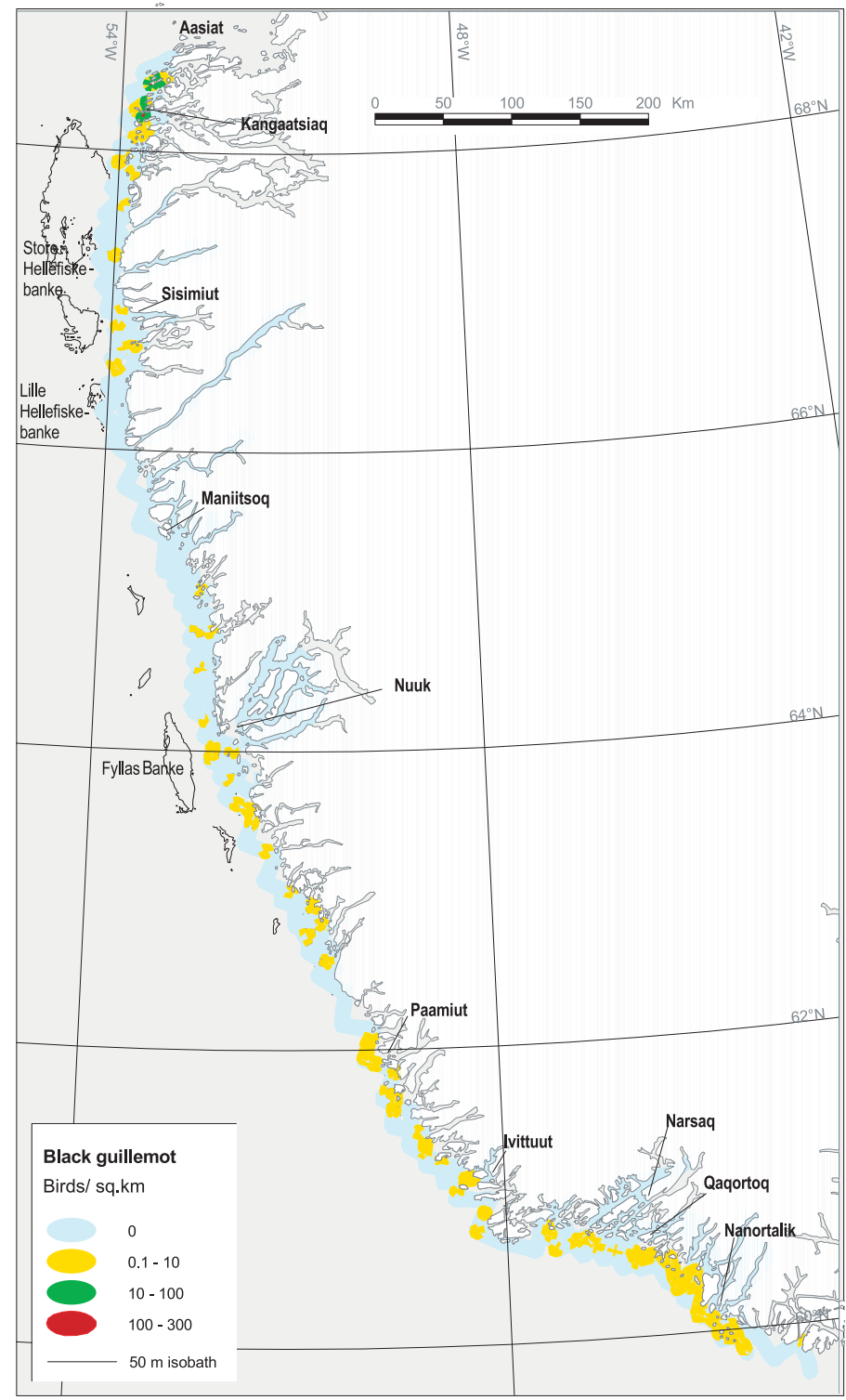

Fig. 6. Distribution and interpolated densities of black guillemot in south-west Greenland, February/ March 1999.

the separation point (Coastal A and B) (Table 3). Detectability of the murres was reduced close to the track line, due to the frequency of escape diving at this range. Furthermore, the white flank of the murres is not visible when observed directly from above, making them harder to detect close to the track line. As a consequence we lefttruncated distance data at $50 \mathrm{~m}$. For dataset A this implied a removal of ca. $27 \%$ of the sightings, and for dataset B ca. $15 \%$. The final abundance estimate was calculated at 125439 (95\% CL:
78091 - 201497) wintering murres at the coastal zone, of which more than $80 \%$ were estimated from dataset $\mathrm{B}(\mathrm{S}>10)$ (Table 3$)$.

\section{Black guillemot}

Black guillemot was the fifth most common bird observed in the survey (Table 1), with an average density of 0.5 birds $/ \mathrm{km}^{2}$ (Table 2). Birds were dispersed singly or in small flocks throughout most of the coastal survey area (Fig. 6). The 
highest density was observed in the northern dense pack ice around Kangaatsiaq, but density was also high around Nanortalik, where there was no ice. From around $65^{\circ}$ to $66^{\circ} 30^{\prime} \mathrm{N}$, and at a small area north of Paamiut, no birds were seen at all; these were the same places at which thickbilled murres were very scarce. In some areas black guillemot were most abundant to the west in the survey area, indicating that their presence continued further west. Birds were seldom seen in the fjords; only five sightings were detected (Table 1).

Black guillemot responded to the approaching survey airplane much like the murres did, mainly by escape diving (Table 2). The proportion of diving birds versus birds on the water differed between areas, though this was not statistically significant $\left(\chi_{3}^{2}=3.8 ; \quad P=0.28\right)$. As with the murres, there was a tendency for escape diving to occur most frequently close to the track line.

As with the murres, data were left-truncated at a distance of $50 \mathrm{~m}$, corresponding to a $13 \%$ reduction in sample size. In spite of a rather variable sighting rate at the coastal zone, the most robust abundance estimate was produced without any geographical post-stratification. The number of wintering black guillemots at the coastal zone was estimated at 12030 (95\% CL: 5335-27128) birds. Most of the abundance variance can be ascribed to a minor proportion of the sightings, for which flock size was higher and more variable than for the majority. As much as $75 \%$ of the sightings consisted of single bird observations (Fig. 6).

\section{Non-quantified species}

Fulmar-Eighty-two sightings of fulmars with a total of 1153 birds were detected during the survey (Table 1). Except for a single observation, all fulmars were airborne at the time of detection (Table 2), rendering the sightings inadequate for distance sampling analyses. Fulmars were detected on 22 of 127 transects, of which 21 were positioned within the most central portion of the open water area $\left(65^{\circ} 50^{\prime}-62^{\circ} 35^{\prime} \mathrm{N}\right)$. Here birds occurred in patches with the highest concentration to the west, indicating a further distribution to the west. One transect at the southern tip of Greenland accounted for 35\% of all detected birds. Apart from this transect, no birds were detected north and south of the specified area or in the fjords.
Great cormorant.-Great cormorants were found throughout the coastal zone, although very scarce at some regions. Regular findings were done from Kangaatsiaq and halfway to Sisimiut $\left(68^{\circ} 20^{\prime}\right.$ $\left.67^{\circ} 43^{\prime} \mathrm{N}\right)$, between Maniitsoq and Nuuk (65 $15^{\circ}$ ' $\left.-63^{\circ} 45^{\prime} \mathrm{N}\right)$, and in the Julianehåbsbugten area $\left(60^{\circ} 42^{\prime}-59^{\circ} 50^{\prime} \mathrm{N}\right)$. Birds were recorded on 40 of 127 transects, with a total number of 556 individuals (Table 1). Birds were confined to nearshore coastal areas, and were often resting on small islands. They all took flight at the approach of the survey airplane (Table 2). Additionally, 136 birds were seen in the fjords, mainly in the Julianehåbsbugten area.

Mallard.-Mallards were seen in near-shore local concentrations at the coastal zone, mainly around Nuuk and at the Julianehåbsbugten area. A total number of 252 birds were recorded on 13 of 127 transects (Table 1). No mallards were detected north of $64^{\circ} 52^{\prime} \mathrm{N}$ or in the fjords.

Harlequin duck (Histrionicus histrionicus).Only four sightings (45 birds) of harlequin duck were made during the survey. These were located at Ydre Kitsissut $\left(60^{\circ} 45^{\prime} \mathrm{N}\right)$, an area specifically searched as some of the uplinks from Canadian satellite tracked birds came from these islands (Brodeur et al. 1998), and at two locations south of Nuuk (63'59' $\mathrm{N}$ and $\left.63^{\circ} 3^{\prime} \mathrm{N}\right)$. Many individuals of this species must have been overlooked by this survey, partly because of their small size, but mainly due to its habitat preferences.

Red-breasted merganser.--Red-breasted merganser was occasionally seen in small numbers at the coastal zone, strictly confined to the coastline. Birds were most regularly encountered from around Nuuk and $180 \mathrm{~km}$ to the south, and in the Julianehåbsbugten area. A total of 79 birds were recorded (Table 1).

Kittiwake.-At the coastal zone kittiwake sightings were restricted to the most central region $\left(60^{\circ} 42^{\prime}-59^{\circ} 50^{\prime} \mathrm{N}\right)$, a distribution tendency similar to the one observed for fulmars. Birds were distributed, in small numbers, almost evenly in this area (Table 1). High densities of kittiwakes were found in the fjord system around Maniitsoq. A total number of 3200 birds were counted here. The Maniitsoq fjord system is also known as the most important kittiwake breeding site in Greenland (Boertmann et al. 1996). Kitti- 
wakes were not seen elsewhere in fjords.

\section{Discussion}

\section{Overall distribution and abundance}

Surveying the entire coastal zone for the first time, this study confirms that coastal habitats off south-west Greenland are important seabird wintering grounds (Salomonsen 1950, 1979; Durinck \& Falk 1996). This study also documents the importance of several fjord systems as winter habitats for common eider.

Common eider, king eider, long-tailed duck, thick-billed murre and black guillemot were the most widespread and numerous species, with a combined estimate of 850000 birds. Considering that aerial surveys normally produce conservative estimates (see below), and the fact that not all fjords were surveyed, is it likely that the actual total winter population of these five seabird species exceeds one million birds within the fjords and coastal areas covered in this study. With high densities and species diversity at the coastal zone, and highly concentrated aggregations of common eiders in the adjoining fjord systems, the waters around Nuuk and the Julianehåbsbugten area were identified as important seabird areas.

\section{Distribution and abundance: coastal species}

Among the 15 seabird species recorded, six had their predominant distribution confined to shallow waters at the coastal zone or parts of fjord systems. These species - common eider, long-tailed duck, great cormorant, mallard, harlequin duck and red-breasted merganser-are all associated with shallow waters. They feed on molluscs, crustaceans, echinoderms or fish (Salomonsen 1967; Cramp 1977). Except for the harlequin duck, these species were ideal to monitor with the present survey design, although mallards and red-breasted mergansers were too few in number to allow quantitative analyses. Distribution and abundance of moulting/wintering harlequin ducks has since been studied by alternative survey methods (Boertmann \& Mosbech 2001; Boertmann \& Mosbech unpubl. ms.)

This study has produced the first available estimates for common eider and long-tailed duck. Our estimate represents the total number of wintering birds off south-west Greenland, although these numbers may to be conservative for the following reasons. First, we only surveyed about $45 \%$ of all fjord areas. Although fjords believed to harbour high densities of eiders were preferentially selected for surveying, and many non-surveyed fjords between Ivittuut and Nuuk $\left(61^{\circ}-64^{\circ} \mathrm{N}\right)$ are usually completely ice-covered (Mosbech et al. 2000), there were very likely some birds in the unsurveyed fjords. In addition, aerial surveys conducted in March/April 1998 indicated that a few common eiders might occur to the west of the coastal survey area (Heide-Jørgensen et al. 1999). Common eider has a maximum recorded diving depth of around $20 \mathrm{~m}$ (Bustness \& Lønne 1997; Cramp 1977), and water depths within this range do occur at offshore banks, although they are rare (Mosbech \& Johnson 1999). They might also use offshore waters as resting locations, or to avoid human hunting along coasts.

The 1998 aerial survey also showed that longtailed ducks occasionally could be seen west of the coastal zone (Heide-Jørgensen et al. 1999). However, observations were very rare, and limited to seven sightings within an area of $43250 \mathrm{~km}^{2}$ (Fig. 1). Except for our 1998 survey, no previous surveys have reported long-tailed duck west of the 1999 coastal survey zone (Durinck \& Falk 1996; Mosbech \& Johnson 1999). Apparently, long-tailed ducks are absent in fjords, and therefore the coastal survey zone covers the entire long-tailed duck winter distribution range in west Greenland. We consider the estimate of 94382 birds (95\% CL: 66943 - 133 070) to represent the total number of long-tailed ducks wintering off south-west Greenland.

\section{Distribution and abundance: offshore species}

King eider, thick-billed murre, black guillemot, fulmar and kittiwake were all frequently observed in the coastal survey area. However, we anticipated on the basis of earlier surveys that these species - in contrast to the coastal specieswould be distributed west of the coastal zone as well. Characteristically, they were distributed rather evenly from east to west at the coastal survey zone, and some of them even concentrated offshore to the west. Previous aerial and shipbased surveys conducted in February-April found king eiders at high densities on offshore shallow banks (Store Hellefiskebanke and Fyllas Banke). Thick-billed murres occurred offshore 
on the continental shelf as well as on shallow banks, black guillemots on offshore pack ice throughout the Davis Strait and Baffin Bay, and fulmars and kittiwakes dispersed on most ice-free waters (Durinck \& Falk 1996; Heide-Jørgensen et al. 1999; Mosbech \& Johnson 1999). Thus, the abundance estimates for king eider, thick-billed murre and black guillemot published in this paper represent only birds found coastally, and constitute an unknown proportion of the southwest Greenland winter population: this survey cannot estimate population sizes for these species nor serve as a basis to detect population trends with future surveys. In addition, ice conditionsshown to be crucial for the offshore distribution of several species (Mosbech \& Johnson 1999)in the Davis Strait vary considerably from one year to another.

\section{Detection efficiency}

An assumption of the line transect survey method is that all individuals on the track line are detected (Buckland et al. 1993). However, in practice weather conditions may reduce detectability, or birds may behave in such a way that they are hard to detect. In this study we conducted several test surveys to provide more precise estimates and facilitate reproducible surveys (Heide-Jørgensen et al. 1999).

Submergence, the predominant avoidance response among thick-billed murre and black guillemot (Table 2), clearly brought down the detection efficiency on the track line to below $100 \%$. As the response occurred most frequently close to the track line, the problem could partly be solved by a left truncation of the distance data. Still, we must expect some degree of escape diving beyond the truncation distance of $50 \mathrm{~m}$. This behaviour was most pronounced for the alcids, making aerial surveys less suitable for counting them. For all other species, including eiders, submergence appeared to be a minor problem (Table 2).

Non-alcid birds took flight as the most frequent response to the approaching airplane. In contrast to the diving response, this often took place some distance ahead of the airplane. The behaviour as such did not reduce detectability, but the important question is whether airborne sightings can be represented by the parameters (flock size, ESW) calculated from sightings detected on the water. However, as earlier argued, we believe this is justified in a conservative estimate.

For both eider species and long-tailed ducks, a significantly higher proportion of birds took flight north of $66^{\circ} \mathrm{N}$. We cannot explain why this is so. However, we speculate that it might be related to the frequency of human disturbance in this region. At the coastal areas with low flight reaction, weather had been rough for several days prior to the survey, preventing hunting and postponing our own surveying. Maybe this period of non-disturbance reduced the alertness of the birds. Another possible explanation is that the sound pressure of the airplane noise might be influenced by ice coverage, which certainly was higher to the north.

Detectability is also related to the efficiency of the observers. It has long been recognized as a methodological problem for line transect surveys that the assumption of $100 \%$ detectability on the track line fails due to observers overlooking individuals (Pollock \& Kendall 1987). Using traditional methods to solve this problem, e.g. double-observer experiments, is seldom an option in bird cases as densities of birds are usually too high to allow positive recapture identification. During this survey, a video recorder was attached at a bottom window of the airplane. However, the method turned out to be inadequate as birds could not be positively identified on the videotape. Clearly, methods to derive correcting factors for missed bird observations on the track line are needed.

\section{Conservation concerns}

The high density of seabirds throughout the coastal zone accentuates several management issues of concern, including vulnerability to oil pollution (Mosbech et al. 1996). Exploratory drilling has already taken place in the Fylla area (summer 2000), and more is expected. This study clearly shows that exposure to oil of any littoral region along south-west Greenland is likely to impact a substantial number of seabirds. An unknown proportion of common eider may avoid oil deep inside the fjords, assuming they never travel to the coastal zone.

Seabirds are heavily hunted at the coastal zone. Hunters' reports on monthly bags (1994-99) produce a minimum average number of 165000 thick-billed murres and 55000 eiders (king and common) that are harvested each winter in southwest Greenland (the actual takes are probably 
higher). These numbers represent $80 \%$ and $70 \%$ of the total annual catch of murres and eiders in Greenland, respectively (Dept. of Fishing and Hunting, Greenland Home Rule). As south-west Greenland is an important international wintering area for both thick-billed murres, king and common eider, there is concern that an excessive harvest might affect various breeding populations within the circumpolar region. Serious declines have been detected at colonies of thick-billed murre and common eider in Greenland (Kampp et al. 1994; Frich et al. 1998; Merkel 2002), thickbilled murre colonies in Iceland (Gardarson 1995; Natturufrædistofnun Islands 2000), and eastern Canadian king eiders moulting in west Greenland (Gratto-Trevor et al. 1998; Mosbech \& Boertmann 1999). It is generally assumed that these cases are related to the harvest in Greenland; however, due to insufficient information about the size of the total winter population it is unclear to what extend the winter harvest is responsible. Our estimates for common eider and long-tailed duck greatly improve the possibility of assessing the sustainability of the winter harvest. As argued, the estimates are considered rather conservative. From a management perspective, this is not a major drawback as it will lead to management on the safe side rather than promoting unsustainable over-harvesting. Furthermore, it should also be taken into consideration that the hunting statistics upon which management is partly based are likely influenced by under-reporting (Frich 1997b; Falk \& Kampp 2001). Thus, while actual bird numbers may be somewhat higher than reported here, so are hunting offtakes.

For the common eider this study emphasizes the importance of south-west Greenland as a wintering area for the eastern Canadian breeding population. For quite some time it has been known that nearly all the king eiders originate in the Canadian Arctic (Salomonsen 1968). However, for common eider ( $S$. m. borealis) the magnitude of influx from Canada has been uncertain. From band recoveries it is known that only birds from western Greenland and eastern Canadian Arctic winter in south-west Greenland (Salomonsen 1967; Abraham \& Finney 1986; P. Lyngs, pers. comm. 2000). Based on recently conducted surveys, it is estimated that a maximum number of 15000 pairs breed in western Greenland (Merkel 2002), implying that the vast majority of the conservatively estimated number of 463000 wintering common eiders originate in the eastern
Canadian Arctic.

\section{Recommendations for management and future studies}

Future aerial surveys of south-west Greenland waters should preferably be extended to include the offshore shallow banks, Store Hellefiskebanke, Lille Hellefiskebanke and Fyllas Banke since this would permit a complete coverage of the king eider distribution range. Recently conducted satellite telemetry of king eiders in west Greenland suggest that there is only little interchange between coastal birds and birds using the offshore shallow bank Store Hellefiskebanke (Mosbech et al. 2001).

To include the total distribution range of thickbilled murre, as well as other offshore species, would mean a further extension of the survey area. This would be difficult, considering the unstable weather conditions in south-western Greenland at this time of year.

For the common eider we recommend using the population estimate presented here to advance the assessment of the sustainability of the winter harvest in west Greenland. In fact, this process has already been initiated, and a preliminary computer model that simulates population dynamics for the northern common eider population $(S . m$. borealis) in Greenland and Canada has now been developed (Gilchrist et al. 2001). A similarly useful estimate now exist for the long-tailed duck population wintering in west Greenland. However, hunters are not currently bound to supply bag records for the harvest of this species. Unfortunately this means that sustainable harvest assessments are yet not possible for this species. Long-tailed duck is a fairly common game bird during wintertime, and future inclusion in the bag record programme would be highly recommended.

Fjord systems obviously provide important winter habitat for the common eider. However, judging by bird distribution and behaviour, the fjords might also play a somewhat different role from coastal habitats. The fjord birds congregate to form huge and very densely packed flocks. In contrast, eiders at the coastal zone are distributed rather evenly as individuals or in small groups. From an ecological point of view, as well as for management purposes, it is necessary to study the relationship between coastal and fjord birds. Currently, it is not known whether these 
populations are distinct, or if fjord eiders move out to join coastal populations throughout the winter or vice versa. If little or no interchange occurs, the coastal eider population is certainly exposed to a steadily high hunting pressure.

Based upon this study, the Nuuk and Julianehåbsbugten areas support one third of the total common eider winter population (Table 4). Cities and settlements within these two areas also support about $40 \%$ of the Greenlandic human population and, in consequence, both areas are heavily hunted. Approximately 25000 eiders are shot each winter (1994-99), comprising almost half (45\%) of the eider harvest in southwest Greenland (Dept. of Fishing and Hunting, Greenland Home Rule). Moreover, associated disturbances might affect body condition in such a way that reproductive performance is reduced. Such issues need attention.

Finally, in the context of oil pollution seabird studies that aim at forecasting their distribution and abundance during winter are recommended. Studies that relate bird distribution to habitat factors such as salinity, temperature, depth, ice cover etc. would allow elaboration of forecast scenarios.

Acknowledgements.-We wish to thank M. P. HeideJørgensen, Greenland Institute of Natural Resources, for great support and methodological advice during preparation of the survey programme, as well as during the initial data analysis. Thanks to the pilot Leif Petersen, Danish Air Survey ApS, for skilled navigation of the aircraft and for contributing to the data collection, and to Keld Q. Hansen, Danish Meteorological Institute, who was most helpful in providing satellite images of the ice conditions in west Greenland. Also thanks to Nanette Hammeken who assisted as an observer during parts of the survey. Finally, we are grateful to two anonymous referees who helped us to improve this paper.

\section{References}

Abraham, K. F. \& Finney, G. H. 1986: Eiders of the eastern Canadian Arctic. In A. Reed (ed.): Eider ducks in Canada. Can. Wildl. Serv. Rep. Ser. 47, 55-73.

Beavers, S. C. \& Ramsey, F. L. 1998: Detectability analysis in transect surveys. J. Wildl. Manage. 62, 948-957.

Boertmann, D. 1994: An annotated checklist to the birds of Greenland. Medd. Grønl. 38.

Boertmann, D. \& Mosbech, A. 2001: Important summer concentrations of seaducks in West Greenland. An input to oil spill sensitivity mapping. Tech. Rep. 345. Copenhagen:
National Environmental Research Institute.

Boertmann, D. \& Mosbech, A. unpubl. ms.: The harlequin duck (Histrionicus histrionicus) in Greenland.

Boertmann, D., Mosbech, A., Falk, K. \& Kampp, K. 1996: Seabird colonies in western Greenland. Tech. Rep. 170 Copenhagen: National Environmental Research Institute.

Brodeur, S., Robert, M., Laporte, P., Fitzgérald, G., Marchand, S. \& Savard, J.-P. L. 1998: Recent discoveries about harlequin ducks in eastern North America. On the Internet at http://www.qc.ec.gc.ca/faune/sauvagine/html/hd_risk.html.

Brown, R. G. B. \& Nettleship, D. N. 1981: The biological significance of polynyas to Arctic colonial seabirds. In I. Sterling \& H. Cleator (eds.): Polynyas in the Canadian Arctic. Can. Wildl. Serv. Occas. Pap. 45, 59-65.

Buckland, S. T., Anderson, D. R. \& Laake, J. L. 1993. Distance sampling. New York: Chapman \& Hall.

Burnham, K. P., Andersen, D. R., White, G. C., Brownie, C. \& Pollock, K. H. 1987: Design and analyses methods for fish survival experiments based on release-recapture. Am. Fish. Soc. Monogr. 5.

Bustnes, J. O. \& Lønne, O. J. 1997: Habitat partitioning among sympatric wintering common eiders Somateria mollissima and king eiders Somateria spectabilis. Ibis 139, 549-554.

Cramp, S. (ed.) 1977. The birds of the western palearctic. Vol. I. Oxford: Oxford University Press.

Denlinger, L. \& Wohl, K. 2001: Seabird harvest regimes in the circumpolar nations. CAFF Tech. Rep. 9. Akureyri, Iceland: CAFF International Secretariat, Circumpolar Seabird Working Group.

Durinck, J. \& Falk, K. 1996: The distribution and abundance of seabirds off southwestern Greenland in autumm and winter 1988-1989. Polar Res. 15, 23-42.

Falk, K. \& Kampp, K. 2001: Lomvien i Grønland: mulige effekter af forskellige bestands-påvirkende faktorer, og praktiske granser for ressourceudnyttelse. (The thickbilled murre of Greenland: potential population effects from various protection mechanisms and practical limitations of harvest.) Tech. Rep. 38. Nuuk: Greenland Institute of Natural Resources.

Falk, K., Kampp, K. \& Frich, A. S. 1997: Polarlomvien $i$ Østgrønland, 1995. (English summary: The thick-billed murre in east Greenland, 1995.) Tech. Rep. 9. Nuuk: Greenland Institute of Natural Resources.

Frich, A. S. 1997a: Ederfuglefangst i Grønland 1993. (Eider harvest in Greenland.) Tech. Rep. 9. Nuuk: Greenland Institute of Natural Resources.

Frich, A. S. 1997b: Lomviefangst i Grønland 1993. (Murre harvest in Greenland 1993.) Tech. Rep. 2. Nuuk: Greenland Institute of Natural Resources.

Frich, A. S., Christensen, K. D. \& Falk, K. 1998: Ederfugleoptcellinger $i$ Kangaatsiaq og Avanersuaq 1997. (Common eider ground surveys in Kangaatsiaq and Avanersuaq 1997.) Tech. Rep. 10. Nuuk: Greenland Institute of Natural Resources.

Gardarson, A. 1995: Svartfugl i islenskun fuglabjörgum (English summary: Numbers and distribution of common murre Uria aalga, thick-billed murre $U$. lomvia and razorbill Alca torda in Iceland.) Bliki 16, 47-65.

Gilchrist, H. G., Gilliland, S., Rockwell, R., Savard, J.-P., Robertsen, G. J. \& Merkel, F. R. 2001: Population dynamics of the northern common eider in Canada and Greenland: results of a computer simulation model. Unpublished report. Canadian Wildlife Service. 
Gratto-Trevor, C. L., Johnston, V. H. \& Pepper, S. T. 1998: Changes in shorebird and eider abundance in the Rasmussen Lowlands, NWT. Wilson Bull. 110, 316-325.

Hansen, K. 2002. A farewell to Greenland's wildlife. Copenhagen: G.E.C. Gads Forlag.

Heide-Jørgensen, M. P., Acquarone, M. \& Merkel, F. R. 1999: Flytcellinger af fugle og havpattedyr $i$ Vestgrønland 1998. (Aerial surveys of birds and marine mammals off west Greenland 1998.) Tech. Rep. 24. Nuuk: Greenland Institute of Natural Resources.

Kampp, K., Nettleship, D. N. \& Evans, P. G. H. 1994: Thickbilled murres of Greenland: status and prospects. In D. N. Nettleship et al. (eds.): Seabirds on islands, threats, casestudies and action plans. Birdlife Conserv. Ser. 1. Pp. 133 154. Cambridge: Birdlife International.

Merkel, F. R. 2002: Ederfugleoptcellinger i Ilulissat, Uummannaq og Upernavik kommune, 199 -2001. (English summary: Common eider ground surveys in the municipality of Ilulissat, Uummannaq and Upernavik, 1998-2001.) Tech. Rep. 43. Nuuk: Greenland Institute of Natural Resources.

Mosbech, A., Anthonson, K. L., Blyth, A., Boertmann, D., Buch, E., Cake, D., Grøndahl, L., Hansen, K. Q., Kapel, H., Nielsen, S., Platen, F. V., Potter, S. \& Rasch, M. 2000: Environmental oil spill sensitivity atlas for the west Greenland coastal zone. CD version. Danish Energy Agency, Ministry of Environment and Energy.

Mosbech, A. \& Boertmann, D. 1999: Distribution, abundance and reaction to aerial surveys of post-breeding king eiders (Somateria spectabilis) in western Greenland. Arctic 52, 188-203.

Mosbech, A., Dietz, R., Boertmann, D. \& Johansen, P. 1996: Oil exploration in the Fylla area, an initial assessment of potential environmental impacts. Tech. Rep. 156. Copenhagen: National Environmental Research Institute.

Mosbech, A. \& Johnson, S. R. 1999: Late winter distribution and abundance of sea-associated birds in south-western Greenland, the Davis Strait and southern Baffin Bay. Polar Res. 18, 1-17.

Mosbech, A., Merkel, F., Flagstad, A. \& Grøndahl, L. 2001: Satellitsporing af kongeederfugl $i$ Vestgrønland. Identifikation af raste- og overvintringsområder (English summary: Satellite tracking of king eiders in west Green- land. Identification of staging and wintering areas.) Tech. Rep. 381. Roskilde: National Environmental Research Institute.

Natturufrædistofnun Islands 2000: Válisti 2. Fuglar. (English summary: Red list of Iceland. 2. Birds.) Compiled by A. Ingadottir et al. Reykjavík: Natturufrædistofnun Islands.

Nielsen, P. 1999: Ændringer i effektivitet, udnyttelse og afsætning de sidste 20 -30 år. (Changes in efficiency, utilization and marketing during the last 20-30 years.) In K. Rydahl \& I. Egede (eds.): Seminar om de levende ressourcer. (Seminar on living resources.) Tech. Rep. 20. Pp. 72-77. Nuuk: Greenland Institute of Natural Resources.

Pollock, K. W. \& Kendall, W. L. 1987: Visibility bias in aerial surveys: a review of estimation procedures. J. Wildl. Manage. 51, 502-510.

Reed, A. \& Erskine, A. J. 1986: Populations of the common eider in eastern North America. In A. Reed (ed.): Eider ducks in Canada. Can. Wildl. Serv. Rep. Ser. 47, 156-162.

Salomonsen, F. 1950. The birds of Greenland. Copenhagen: Munksgaard.

Salomonsen, F. 1967. Fuglene på Grønland. (The birds of Greenland.) Copenhagen: Rhodos.

Salomonsen, F. 1968: The moult migration. Wildfowl 19, 5-24.

Salomonsen, F. 1979: Ornithological and ecological studies in S.W. Greenland $\left(59^{\circ} 46^{\prime} N-62^{\circ} 07^{\prime} N\right)$. Medd. Grønl. 204.

Salomonsen, F. 1990. Grønlands fauna. (The fauna of Greenland.) 2nd ed. Copenhagen: Gyldendal.

Thomas, L., Laake, J. L., Derry, F. J., Buckland, S. T., Borchers, D. L., Anderson, D. R., Burnham, K. P., Strindberg, S., Hedley, S. L., Burt, M. L., Marques, F., Pollard, J. H. \& Fewster, R. M. 1998: Distance 3.5. Research Unit for Wildlife Population Assessment, University of St. Andrews, UK.

Valeur, H. H., Hansen, C., Hansen, K. Q., Rasmussen, L. \& Thingvad, L. 1996: Weather, sea and ice conditions in eastern Baffin Bay, offshore northwest Greenland, a review. Tech. Rep. 96-12. Copenhagen: Danish Meteorological Institute.

Valeur, H. H., Hansen, C., Hansen, K. Q., Rasmussen, L. \& Thingvad, L. 1997: Physical environment of eastern Davis Strait and northeastern Labrador Sea. Tech. Rep. 97-9. Copenhagen: Danish Meteorological Institute. 